\title{
HOW TO BE A GREAT PUBLIC SERVICE LEADER?
}

\section{Prof. Datuk Dr. John Antony Xavier ${ }^{1}$}

"Leadership is about lifting a person's vision to higher sights, the raising of a person's performance to a higher standard and the building of a personality beyond its normal limitations".

Peter Drucker

\section{ABSTRACT}

This paper highlights the various skills that are needed to be a great public service leader. Although the public service and the private sector are different in terms of work environment and objectives, the principles of leadership are the same. This is because leadership is about influencing employees to work towards achieving organisational goals.

This paper distinguishes three types of skills that a public service leader should have to bring out the best in his people to achieve organisational goals. The first are the high-concept skills of visioning and the requisite courage and determination to achieve the strategic direction of the organisation. The second are the high-touch or soft skills. These include the components of emotional intelligence and influence. The third are the analytical and technical skills.

Of the three types, soft skills are the most important of these skills. $75 \%$ of effective leadership rests on soft skills. This is because leadership today is increasingly a collaborative and participatory process to motivate employees to produce higher levels of performance. Notwithstanding, the judicious blend of these three skills will greatly enhance a public service leader's impact on his organisation.

To be a great leader in the public service, one would also need to invest in developing people, to become leaders. While formal training is one way of developing leadership, $90 \%$ of leadership training is through informal onthe-job training. Coaching and mentoring play an important role in growing leaders. The sacrifice of time and effort at mentoring and coaching future leaders will enable a public service leader to leave behind a lasting legacy.

Keywords: Leadership, Public Service Environment, Competency Development

\footnotetext{
${ }^{1}$ John Xavier is a professor of management at the Graduate School of Business, National University of Malaysia. He previously worked for 36 years in the Malaysian public service and has been a consultant to the Government of Kuwait, IMF, World Bank, Commonwealth Secretariat, Commonwealth Association for Public Administration and Management and the Arab Administrative and Development Organisation.Prof. John has published a number of articles on management. He holds a Bachelor of Economics from the University of Malaya, Master of Business Administration from the Catholic University of Leuven, Bachelor of Laws from the University of London and Ph.D from the London School of Economics.
} 


\section{The Public Service Environment}

In the movie 'Braveheart' Mel Gibson captivates movie-goers with his masterful portrayal of the great 13th century Scottish patriot - William Wallace. Wallace is revered in legend as a hero, leading his men in battles to reclaim his homeland from the cruel English occupiers. As the title 'Braveheart' suggests, Wallace was a leader of surpassing courage, passion and determination to achieve his vision of freedom for Scotland. He was able to rally his countrymen behind him, give them a common cause and build them up into a force that the English had to reckon with.

Today, the public service requires leaders of the ilk of Wallace. This is because of the change that is taking place in and around the public service today. Increasingly, as the higher echelons retire, younger recruits are occupying more of the middle management positions. They have no one to look up to as a role model except their superiors. Hence, it is important that superiors display leadership qualities worthy of emulation (Batley, 2006, p. 12).

Further, unlike their counterparts in the private sector, public service leaders have a unique set of challenges to contend with:

- For one, their list of stakeholders and customers is longer compared to the private sector's. This is inevitable given the myriad of public services that the public service provides to its customers. What is more, in this consumerist world where private sector performance shames public sector service delivery, the litany of grouses against public service delivery grows ever so louder. This clamour of better service delivery reaches its crescendo in calls for greater transparency and responsive governance. So, leadership is not an option but a necessity in the public service. The days of reaction are over. Today, public service leaders must pro-act to meet the needs of the public.

- Public management leadership has gone through a metamorphosis. In the early days of statehood, the public service was the leader and main player in the nation's development. Since then the public service has transformed itself from being a regulator and driver of development to becoming a facilitator to enable the private sector to take the lead in national development (Batta, 2001, p. 31). This evolution of the role played by the public service leadership is shown in Figure 1 below 


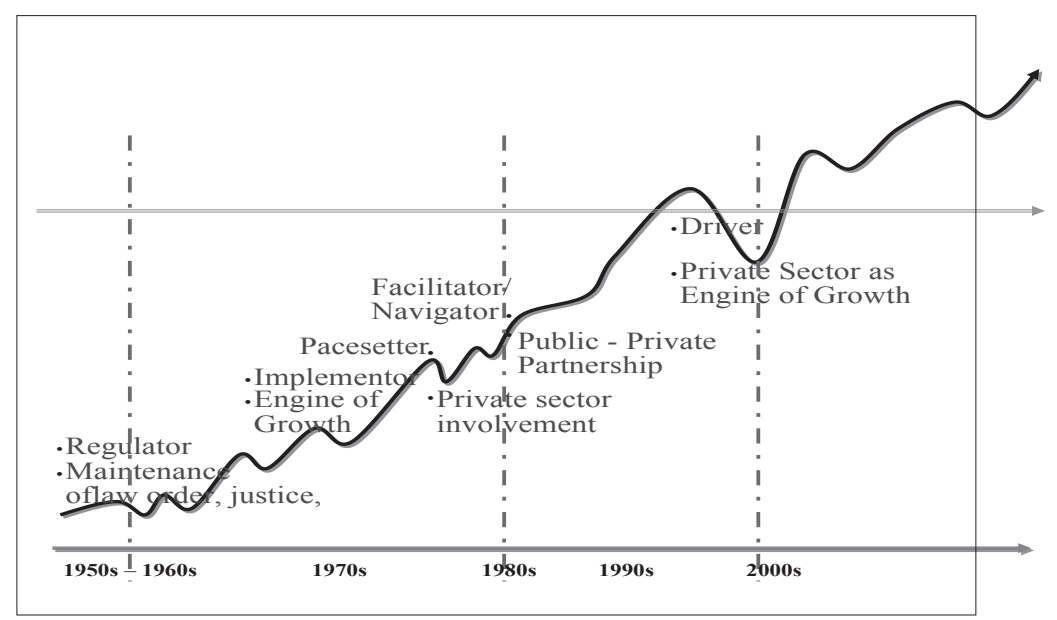

Figure 1: The Changing Role of the Public Service

Adapted from: Ismail Adam, 2006, p. 17

Congruent to these changes, the leadership styles in the public service have also undergone various changes as shown in Figure 2.

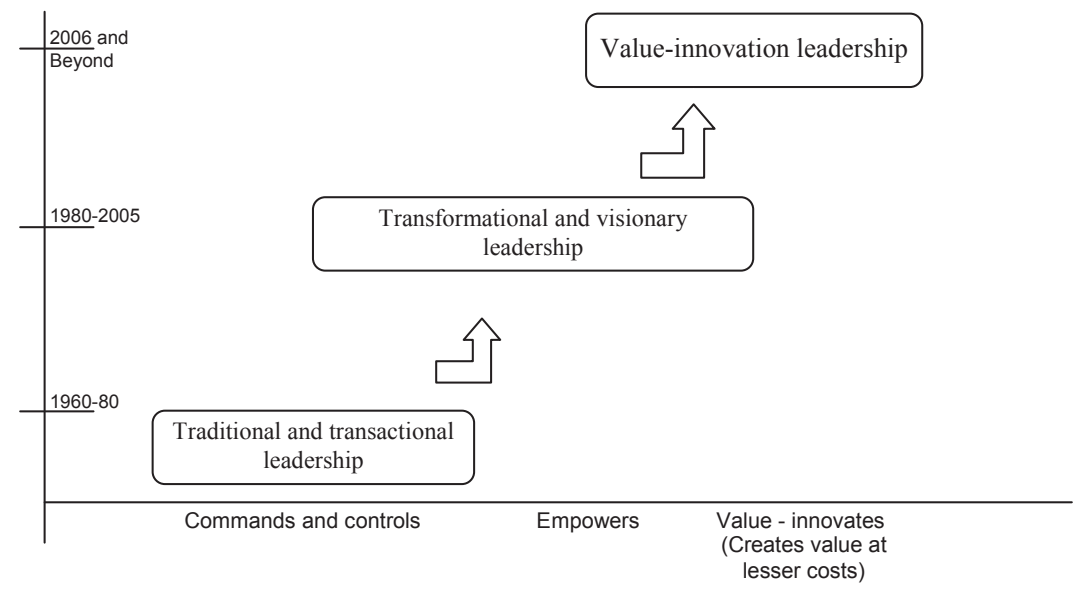

Figure 2: Leadership Transformation in the Public Service

Adapted from: Ismail Adam, 2007, p. 10

Leadership forms have evolved from 'traditional and transactional' through 'transformational and visionary' to 'value-innovation'. Traditional or transactional leadership was necessary in the early days of nation-building. Then, Sri Lanka's main priority was to build its new nation. As Sri Lanka has developed rapidly, it has realised the value in getting its people to work together towards a common future and to increasing its per capita income to USD 4,000 by 2016 
(Mahinda Chintana, 2010, p. 8). Accordingly, leadership forms have moved on to being transformational and visionary to move the nation forward to help realise the aspirations of Mahinda Chintana.

To ensure a resilient and competitive nation, Sri Lanka has to redouble its efforts towards value-innovation leadership (borrowing the term from the 'Blue Ocean Strategy' book of Chan Kim and Rene Mauborgne, 2005, p. 43). Setting a vision for the future is not enough. Given resource constraints, the public service has to become increasingly innovative to achieve the national vision (Mahinda Chintana, 2010, pp. 34-35). We have to become a government that works better yet costs lesser. To be so, we have to enhance service delivery while reducing the costs of services provision.

- There is the further challenge for the public service leadership to ensure the continued relevance of the public service. In the public service, changes which had been gradual in the past, have now gathered pace. There is now no more time for complacency and letting things run their course. Business in the public service is no longer as usual. If we do not deliver, somebody else will deliver for us and render us less relevant. This can take the form of competition from the private sector in service provision or the taking over of public jobs by private sector personnel. To stay relevant, we need to simplify rules, regulations, systems and procedures for better and more efficient service delivery. We now need to find new ways and new roles to play. The 'Blue Ocean Strategy' book of Chan Kim and Rene Mauborgne (2005) offers techniques on how we can eliminate, reduce, raise and create aspects of the public service to make it more dynamic in delivering services.

- Unlike their private sector counterparts, whose sole purpose is to enlarge shareholder wealth, public service leaders have manifold objectives. These range from being efficient and effective in service delivery to achieving national goals of national competitiveness, public interest protection, environmental sustainability, social welfare and income equity.

- Public service leaders have to contend with a highly regulated bureaucracy. The public service has employees many times more than companies. Managing such massive numbers requires rules and regulations to ensure public accountability and the preservation of public interest.

- Security of tenure of public servants makes human resource management a load more challenging than the 'bad hire quick 
fire' environment of the private sector. Unlike their private-sector counterparts, public service leaders cannot choose their employees.

- With the passing of the older generation which was more pliant, if not servile and subservient, the younger generation of public servants wants to be in control of its destiny. Younger public servants want to be empowered. They do not like to be micro-managed.

- In the private sector, an individual leader can make quick decisions. In the public service, however, given diffused power structures, an individual leader does not have the requisite authority to make decisions himself. He has to rely more upon persuasion and political currency to create conditions for the right decisions to be made (Giuliani, 2012, p. 174).

Given these challenges leading public service organisations is a lot harder than before. Despite these challenges, there is a lot going for public service leaders:

- Although they do not match the higher private-sector salaries, public service pay scales are adequate enough to attract and retain the desired talents. Human resource flexibilities afford opportunities for leaders to align human resource management to the strategic direction of the organisation in a way that will allow the organisation to achieve its goals.

- Like any human being, public servants are good by nature. They want to do a good job if given the opportunity to do so. They want to be empowered and be part of a winning organisation. If treated well with respect they can be loyal and will extend their discretionary effort to meet organisational goals efficiently and effectively (Liff, 2007, p. 187).

These positive features of the public service help make leadership in the public service less strenuous. Notwithstanding the different environments in which the public service and the private sector operate, the principles of leadership developed much in a private sector setting are very much the same across the divide. This is because leadership is very much a human activity within a group or organisation. It is increasingly a collaborative, social and relational process. Leadership is about managing resources, especially people, to achieve the organisational vision and mission. It is about bringing out the best in people - through visioning, inspiration and motivation - so that they can unleash their discretionary effort with abandon to achieving organisational goals (Canton, 2006, p.332). 


\section{Leadership Competencies}

The very essence of leadership is that you have to have a vision. Theodore Hesburgh

As with Wallace of the movie Braveheart, public service leaders need both the hard and soft skills. Thomas Friedman in his book "The World is Flat" categorises these as the 'high concept' and 'high touch' skills respectively. $\mathrm{He}$ argues that for the $21 \mathrm{st}$ century-leader to survive in a fast-changing world, he or she must have the high concept skills of visioning and the high touch skills of self-awareness, motivation, empathy, communication and caring.

Additionally, leaders must be team players, results oriented, self-confident and of high integrity. They must be able to communicate and display emotional maturity, including empathy ('high touch' competencies). Critical competencies that public service leaders must have are people skills, visionary leadership capability and skills in decision-making. Table 1 rank orders these competencies (See Rose Lena Lazemi and Siti Norlailasari, 2007, p. 24).

Table 1: Leadership Competencies in the Public Service

\begin{tabular}{|c|l|}
\hline Rank & \multicolumn{1}{|c|}{ Leadership Competencies } \\
\hline 1 & Community focus \\
\hline 2 & Hold a person accountable \\
\hline 3 & Putting the community above self \\
\hline 4 & Organisational awareness \\
\hline 5 & Effective and influential \\
\hline 6 & Results oriented \\
\hline 7 & Visionary leadership \\
\hline 8 & Adaptive thinking \\
\hline 9 & Emotional maturity \\
\hline 10 & Self-confidence \\
\hline
\end{tabular}

Public services across the world have also identified core competencies for their public service leaders. Table 2 highlights some of the core competencies in the US, UK, Netherlands and Australia. It is apparent from the listing of competencies in Table 2 that the core competencies in public services world-wide are similar. 
Table 2: Core Competencies for the Senior Executive Service in Selected Countries.

\begin{tabular}{|c|c|}
\hline $\begin{array}{l}\text { Executive Core Qualifications } \\
\text { in the United States }\end{array}$ & $\begin{array}{l}\text { Associated Leadership } \\
\text { Competencies }\end{array}$ \\
\hline Leading change & $\begin{array}{l}\text { Continual learning, creativity/ } \\
\text { innovation awareness, }\end{array}$ \\
\hline $\begin{array}{l}\text { Flexibility, resilience, service } \\
\text { motivation, strategic thinking, } \\
\text { and vision }\end{array}$ & Hold a person accountable \\
\hline Leading people & $\begin{array}{l}\text { Conflict management, cultural } \\
\text { awareness, integrity/honesty, and } \\
\text { team building }\end{array}$ \\
\hline Results-driven & $\begin{array}{l}\text { Accountability, customer service, } \\
\text { decisiveness, entrepreneurship, } \\
\text { problem solving, and technical } \\
\text { credibility }\end{array}$ \\
\hline Business acumen & $\begin{array}{l}\text { Financial management, human } \\
\text { resources, and technology } \\
\text { management }\end{array}$ \\
\hline $\begin{array}{l}\text { Building coalitions and } \\
\text { communications }\end{array}$ & $\begin{array}{l}\text { Influencing/negotiating, interpersonal } \\
\text { skills, oral communication, } \\
\text { partnership, political savvy, and } \\
\text { written communication }\end{array}$ \\
\hline
\end{tabular}

Source: Gambir Bhatta (2001)

\begin{tabular}{|c|c|}
\hline $\begin{array}{l}\text { Senior Civil Service } \\
\text { Competence Framework in } \\
\text { the United Kingdom }\end{array}$ & Key attributes \\
\hline Giving purpose and direction & $\begin{array}{l}\text { Creating and communicating a vision } \\
\text { of the future }\end{array}$ \\
\hline Making a personal impact & $\begin{array}{l}\text { Showing the way forward; leading by } \\
\text { example }\end{array}$ \\
\hline Getting the best from people & Inspiring people to give their best \\
\hline Learning and improving & $\begin{array}{l}\text { Drawing on experiences and new } \\
\text { ideas to improve results }\end{array}$ \\
\hline Thinking strategically & $\begin{array}{l}\text { Harnessing ideas and opportunities to } \\
\text { achieve goals }\end{array}$ \\
\hline Focusing on delivery/outcomes & $\begin{array}{l}\text { Achieving VFM (value-for-money) } \\
\text { and results }\end{array}$ \\
\hline
\end{tabular}




\begin{tabular}{|c|c|}
\hline $\begin{array}{l}\text { Competency Clusters for } \\
\text { Senior Managers in the } \\
\text { Netherlands }\end{array}$ & Competencies \\
\hline Coherent governance & $\begin{array}{l}\text { Vision of the future, target orientation, networking } \\
\text { skills, leadership }\end{array}$ \\
\hline Problem solving & $\begin{array}{l}\text { Information analysis, judgement, conceptual } \\
\text { flexibility, resoluteness of purpose }\end{array}$ \\
\hline Interpersonal behaviour & $\begin{array}{l}\text { Listening skills, interpersonal sensitivity, flexible } \\
\text { behaviour, collaborative skills }\end{array}$ \\
\hline Operational effectiveness & Initiative, control, delegation, fast interplay \\
\hline Impact & $\begin{array}{l}\text { Oral communication, self-confidence, convincing } \\
\text { power, tenacity }\end{array}$ \\
\hline Resilience & $\begin{array}{l}\text { Energy, stress resistance, performance motivation, } \\
\text { learning capacity }\end{array}$ \\
\hline Governance sensitivity & $\begin{array}{l}\text { Environmental awareness, governance affinity, } \\
\text { integrity, dedication }\end{array}$ \\
\hline
\end{tabular}

\section{Senior Executive Leadership \\ Capability Framework in Australia}

Shaping strategic thinking

Achieving results

Cultivating productive working relationships

Exemplifying personal drive and integrity

Communicating with influence

Resilience

\section{Competencies}

Including inspiring a sense of purpose and direction, focusing strategically, harnessing information and opportunities, showing judgement and common sense

Including building organisational capability and responsiveness, marshalling professional expertise, steering and implementing change, and ensuring closure and delivering intended results

Including nurturing internal and external relationships, facilitating partnerships, valuing individual differences and diversity, and guiding, mentoring, and developing people

Including demonstrating public service professionalism and probity, engaging risk and showing personal courage, displaying resilience, and demonstrating selfawareness and a commitment to personal development

Including communicating clearly, listening, understanding and adapting to audience, and negotiating persuasively

Energy, stress resistance, performance motivation, learning capacity 
The rest of the section will amplify those competencies that public service leaders must possess for organisational excellence. The section divides itself into three types of competencies that are required of a public service leader:

- 'High concept' skills. These skills relate to skills in setting the strategic direction - vision, mission, goals. These also relate to realising this strategic direction through ensuring its buy-in by employees and putting in place a series of decisions and actions to realise the strategic direction.

- 'High touch' skills. These skills relate to emotional intelligence. These include self awareness, self regulation, passion and motivation, empathy and social skills.

- Technical skills. These are skills required to do the job. In a research context, as in the universities, these skills would include research and analytical skills. In a corporate environment planning skills would figure more prominent. And in a training environment, training skills will be highly relevant.

\section{'High Concept' Skills}

This section will discuss leadership skills in setting the strategic direction and in executing 'tipping point' leadership, that is, ensuring that resources are primarily devoted to mission critical activities. It will also highlight the importance of being decisive in decision-making if a leader wants to see execution of the strategic direction of the organisation.

The will to lead - setting the strategic direction

Leadership is all about setting a vision for the future of the organisation and having the ability to translate the vision into results. To be a great leader in the public service, one must have the will to lead. The will to lead is demonstrated when the leader takes charge of his organisation. $\mathrm{He}$ can delegate authority to his subordinates. However, he cannot delegate responsibility to lead his organisation or, worse, abdicate his responsibility to lead. Responsibility sticks like a glue to the leader. What is this responsibility? Primarily, it is to bring meaning to the workplace and to help the organisation succeed in realising its goals (Maira, 2002, p. 108).

That would, firstly, warrant a leader to set the strategic direction of the organisation by developing a vision, mission and value statements. Often, a leader sets the vision of the organisation with a tinge of fantasy and 
idealism. Without full information - it never exists except in a perfect world - he can only look into the future darkly. He can never determine with any mathematical precision as to where the organisation should be headed. This visioning is more creative than scientific thinking. That requires courage and a leap of faith into the future.

Wallace in Braveheart started his crusade against the English invaders out of revenge for his father's and brother's murder at the hands of the English. When his wife too fell victim to the oppressors, he began his long quest to make Scotland free again. That called for courage and for taking charge of the hundreds of his townsmen who rallied to his cause. Wallace rose to the occasion. He took action. He risked his own life to save the lives of others. He led-being the first in battle. He knew his objective. He sought their achievement in the best manner possible.

The ability to define a vision sets the leader from the rest of the pack. Setting the vision calls for a leader to see around the corners and connect the signals (the dots) in the environment to discern emergent trends that impinge on service delivery. Often, it is too easy for us to get immersed in the everyday trivialities and activities that we lose our handle on the bigger and more important things. As leaders we need to focus on the bigger picture (Friedman, 2006, p. 178).

For example, if the public is becoming more internet savvy, which they already are, then service delivery should become more biased to being internet-based. The public service realised that training and development will figure prominently in public human capital development. Accordingly, national training institutes have been established to cater for the expanded need for training in the years ahead.

Setting the strategic direction alone is not enough. Leaders must be able to translate their strategic direction into results. A leader must take the lead in improving performance. He must set challenging yet achievable goals. To do that, public service leaders should ensure that there is buy-in among the followers. Buy-in and enthusiasm towards realising the strategic direction can be readily obtained if the staff had had a hand in crafting the strategic direction. Alternatively, a communications blitz must be instituted to share the vision with the rest of the organisation.

Leaders must also ensure that the strategic direction influences and is influenced by the other elements of the organisation. It is important for a leader to take the next steps to ensure that the culture, strategy, structure, systems and processes - especially human resource management - and organisational skills are aligned to contribute to achieving the strategic direction of the organisation. Bureaucracy has to be slashed. Individuals 
have to be empowered after they have been given performance targets aligned to achieving organisational goals. The leader must treat these targets as solid commitments that staff must keep. Leaders have to be tough (not hard) on their staff respecting achievement of these targets. When Jack Welch headed General Electric, he demanded high standards. He monitored management performance against exacting performance targets. And that was the play right down the organisational hierarchy (Heller, 2001. p. 20).

All these not only require courage. They also require the commitment of the leader. The leader should take charge. It is the personal courage and commitment of a leader, which leads him to become great. Braveheart Wallace knew his goal. He had commitment, or, in Robert the Bruce's (another character in the film) words - "Fire and passion!" At heart, William Wallace never yielded his desire for Scotland's freedom for a peaceful life in bondage. He would not settle for less. He died at the torturer's hands crying out, "Freedom!"

Figure 3 below illustrates the McKinsey capacity building framework. As the figure shows, the element 'aspirations' is at the apex of the pyramid of organisational excellence. It attests to the central importance of leadership in setting the strategic direction. It also highlights that it is important for a leader to see that the rest of the elements determining organisational excellence cohere with the requirements for achieving the strategic direction.

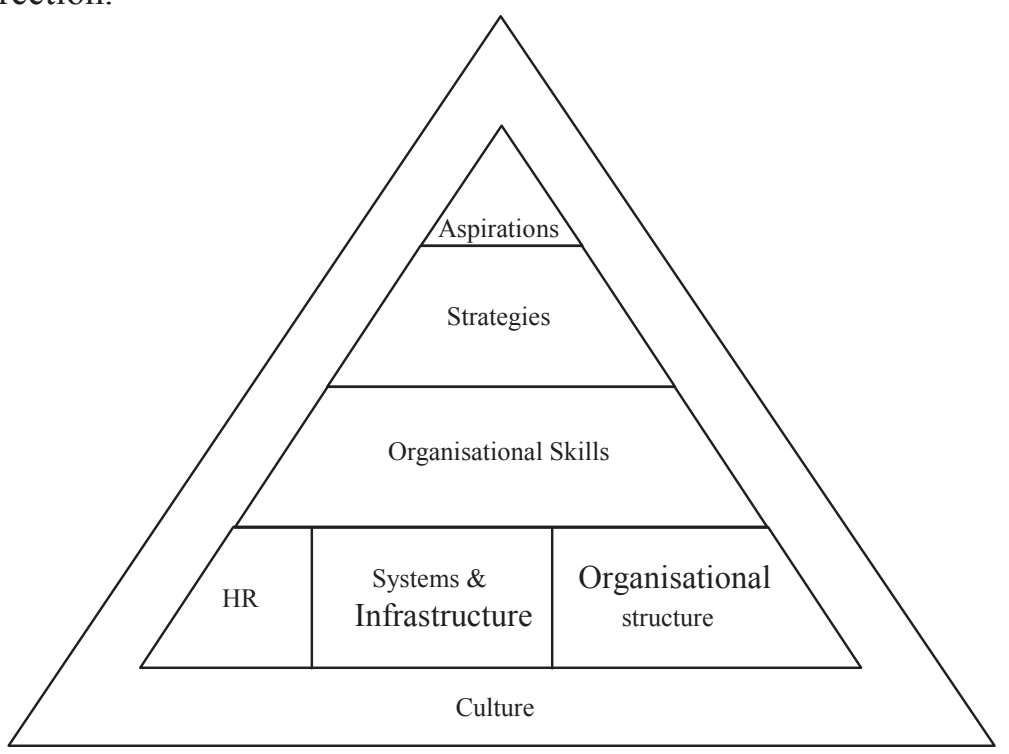

Figure 3: The McKinsey Capacity Framework

Source: McKinsey \&Co., 2001, p. 33 
McKinsey conducted a study on capacity building for enhanced performance among non- profit organisations in 2001. It found that the very act of setting the strategic direction resulted in organisations improving their performance tremendously. This could be because employees take the cue from the organisational vision and mission as to how they should contribute their time and energy. They no longer see their work as a series of tasks to be performed. Rather, they see it as contributing to the noble vision of their organisation. Hence, they see meaning to their work. They derive a sense of satisfaction and accomplishment when their work contributes to noble ends (McKinsey, 2001, p. 37).

Beyond employees seeing meaning and nobility in their work, the leader must show passion for achieving the strategic direction. Braveheart Wallace did show passion beyond bounds. He would not stop at nothing short of routing the English oppressors. The leader must have the energy to energise the organisation so that the staff rally behind him. Such principles of leadership can be summed up in Jack Welch's formula: E to the fourth power (Heller, 2001, p. 23). E stands for:

- Energy, that is, one must have the strength and passion to lead. A leader must have the ability to accomplish results through others by motivating, inspiring and effectively deploying them to execute and implement the organisation's strategies and plans.

- Energising others, that is, a leader must focus attention on the needs of the organisation and the people in the organisation. He must be able to inspire their best efforts, bringing the best in them both as individuals and a team so that they are empowered to realise the strategic direction of the organisation. Energising the team is also about keeping its energy levels buoyed to ensure complete involvement on a continuous basis. It also means showing faith in the team by delegation of authority and requiring the requisite accountability. He must be able to inspire confidence in the organisation's vision and strategies and arouse the organisation's ability to achieve them.

- Competitive Edge. Competitive edge is about developing a comparative advantage to compete in the marketplace. In the public service, that would translate as honing the key strengths of the organisation to deliver services efficiently and effectively. Braveheart Wallace knew his competitive edge. He was careful to pick his fight. Then, he did all he could to win that fight. In other words, he knew his strengths and did all he could to achieve his objective in the best way possible.

Likewise, the public service leader must know where the organisational strength lies and tailor service delivery accordingly. That way he will be able to offer a unique value proposition to his or her stakeholders while achieving his or her objectives successfully. For example, 
if local authorities know that their strength does not lie in garbage collection, then it is best to outsource them.

- Execution. Most ideas and plans fail for want of execution. A leader should, therefore, be persevering in execution. He must have the foresight plus an unrelenting determination to execute the strategic direction and plan of the organisation. He or she must decide and act quickly to solve problems and plan ahead to prevent crises. He or she must act on opportunities and create opportunities for future success (Heller, 2001, p. 33).

Setting the strategic direction is transformational leadership true and true. Transformational leaders provide compelling visions of a better future. Braveheart Wallace provided a compelling vision of a better future for Scotland - freedom from English occupation - to the Scottish plebeians and patricians. Transformational leaders inspire trust through seemingly unshakeable self-confidence and conviction (Collins, 2001; Goleman, et al., 2002). They touch the followers' deeper values and sense of higher purpose. Transformational leaders lead their followers onto higher levels of commitment and achievement.

Such transformational leadership requires emotional connectedness with the followers. As Thomas Friedman (2006, p. 231) in his book 'The World is Flat' says, the paradigm of 'command and control' is obsolete. Welcome to the world of 'connect and collaborate'! Braveheart Wallace was a man of peace ("If I can live in peace I will.") He had to wage war to escape bondage to the English occupiers so that he can raise a family and live in peace. His pursuit of peace and freedom demonstrated inner qualities of leadership worthy of emulation. His actions, as well as his commitment to a worthy cause, inspired those around him. William Wallace's leadership was instrumental in leading a nation to freedom.

The public service is in the business of creating the government of tomorrow. Therefore, the public service needs leaders who are able to lead with vision and have the passion to achieve that vision.

The will to lead - tipping point leadership

The final test of leadership is execution. For leaders to make things happen, they have to marshal the resources of the organisation to accomplish the vision. They need to persevere and have the determination to accomplish what they have set out to do. They need to take into account the nitty gritty as well as the big picture. Malcolm Gladwell in his best-seller "Tipping Point: How Little Things Can Make a Difference" argues, among others, that a few can make a difference. He illustrates his point by quoting the success Rudolf Giuliani had as a mayor in combating crime in New York. Giuliani was convinced that if he were tough on petty crimes the overall crime rate in New York would decline; which it did decline significantly 
during his term of office. (Gladwell, 2000, p. 177; Giuliani, 2002, 243).

Extending the analysis of Gladwell, Kim and Mauborgne argue that to make things happen tipping-point leadership is the key (Kim and Mauborgne, 2005 , p. 153). Once an organisation has set the strategy, leadership must execute it against resource constraints and resistance to change. It must motivate the employees to see the change and to make the change happen. Conventional leadership would entail shunting more resources to overcome these obstacles to get the needed results. Tipping point leadership turns this conventional wisdom upon its head. It advocates breaking through these hurdles fast at low cost.

Pivotal to tipping-point leadership is the belief that in any organisation fundamental changes can happen quickly when a critical mass of committed employees gets so passionate about change that they move it. So, a leader, in exhibiting tipping-point leadership, whips up passion and commitment among the staff that have a disproportionate influence in the organisation to effect change. This is going by the 20:80 principle. Here, the argument is that leaders should focus on that $20 \%$ of employees who have $80 \%$ impact on organisational performance.

Such leadership would require working on the employees' mindset so that they would become intrinsically motivated. Tipping-point leaders focus on high impact activities and channel massive resources from areas that do not require them to areas that can produce high impact - either to the bottom line or to the organisational goals (Kim and Mouborgne, 2005, pp. 148-153, Gladwell, 2000, p. 255-256).

Collin Powell also makes such a point in his book "My American Journey - An Autobiography" (1995). His doctrine has been named after him Powell Doctrine of Overwhelming Force. Powell, speaking in the context of military operations, says that to win a war or a battle we should apply overwhelming force. Every resource and tool should be used to achieve overwhelming force against the enemy, so as to minimise casualties and end the conflict quickly. This is well in line with Western military strategy dating at least from Carl von Clausewitz's On War. What is relevant for us is that Powell also applies his doctrine to espouse the point that civilian leaders should also apply overwhelming force - resources, time and effort - in tackling organisational problems. (Harari, 2002, p. 213).

John Kotter, the leadership guru, advocates a similar technique in his latest book "Our Iceberg is Melting" (2007). Kotter and Rathgeber, illustrate with a story of survival of a colony of penguins in Antartica - the eightpoint strategy for change leadership that Kotter had first highlighted in his 1996 book "Leading Change". Kotter and Rathgeber argue that for change to be sustainable, leadership should, among others, create a sense of urgency for that change, create a guiding coalition by getting commitment and conviction to the change effort and be focused, that is not giving up or 
getting diverted to some other agenda (Kotter and Rathgeber, 2007, p. 28).

Apart from concentration and focus of resources - time, money and effort Kim and Mauborgne also advocate a compelling tagline to help internalise the strategy of the organisation among its staff. Gladwell would call it the 'stickiness factor', that is, the message makes an impact. Gladwell argues that for an idea or a product to take off in a massive way, it must convey some message that sticks and that which people are constantly reminded of. He gives the example of the advertisement for Winston cigarettes where the compelling tagline was, "Winston tastes good like a cigarette should." The ungrammatical construction coveted the attention of the public. It created a sensation. Similarly, Wendy's 1984 tagline of "Where's the beef" too riveted the public's attention to its products (Gladwell, 2000, p. 25).

Hence, leadership is about creating a focus through a compelling tagline a tagline that makes a message contagious and memorable. As Jack Welch says, the role of leaders is to drive home the themes that matter. "If you have a simple consistent message, and you keep on repeating it, eventually that's what happens. Simplicity, consistency, and repetition - that's how you get through. It's a steady continuum that finally reaches a critical mass (as quoted in Heller, 2001, p. 97).”

The will to lead - decisiveness in decision-making

The will to lead is also demonstrated in the decisiveness that the leader brings to his or her decision-making. He cannot pussyfoot on matters of organisational concern. Neither can he or she sit on the fence in making decisions. Worse, he or she cannot afford to sit on a decision. He must make decisions in the best interest of the organisation. In the past, this dilatory behaviour on the part of a public service leader was easier than in the private sector. This was because, generally, a public-service leader was not under the discipline of the marketplace. Not anymore. Today, a public-service leader is under the discipline of the marketplace. In matters of services such as health and education - thanks to deregulation - citizens have the freedom to choose from whom - the public or private sector they would purchase such services.

The incessant demands of stakeholders and citizens and the threat - that overhangs a public service leader like a Damocles' sword - that if one does not deliver someone else will, make it even more imperative for the leader to take charge. He must act and act fast if he wants to be respected. He must act and act fast if he does not want to lose the confidence of his stakeholders, citizens, subordinates and peers.

This requires courage in decision-making. It would require reading the pulse and beat of the marketplace. It would require a greater sense of discernment of the needs and expectations of the stakeholders and citizens and tailoring service delivery accordingly (Roslena and Norlailasari, 2007, p. 13). 


\section{'High touch' skills}

'High concept' skills and a certain degree of analytical and technical skills are necessary but insufficient qualities for a public service leader. Softer skills are also essential. Daniel Goleman first coined the term 'emotional intelligence' to describe these softer skills of self-awareness, self-regulation, motivation and social skill. Effective leaders in the public service are distinguished by a high degree of emotional intelligence. IQ and technical and analytical skills are important. However, they are baseline skills; that is, they are the minimum necessary for executing leadership. But emotional intelligence is the sine qua non of leadership. Without it, a person can be well trained, have the best academic qualifications and have a super-charged brain generating smart ideas, he would still not pass muster as a leader (Goleman, 2005, p. 100, Friedman, 2006, p. 187). The components of emotional intelligence are outlined in the table below.

Table 3: The Five Components of Emotional Intelligence

\begin{tabular}{|c|c|c|}
\hline Components & Definition & Hallmarks \\
\hline Self-awareness & $\begin{array}{l}\text { - The ability to recognise and } \\
\text { understand one's moods, emotions } \\
\text { and drives as well as their effect on } \\
\text { others }\end{array}$ & - Self-confidence \\
\hline Self-regulation & $\begin{array}{l}\text { - The ability to control and redirect } \\
\text { disruptive impulses and moods } \\
\text { - The propensity to suspend } \\
\text { judgement } \\
\text { - to think before acting }\end{array}$ & $\begin{array}{l}\text { - Trustworthiness and } \\
\text { integrity } \\
\text { - Comfortable with } \\
\text { ambiguity } \\
\text { - Openness to change }\end{array}$ \\
\hline Motivation & $\begin{array}{l}\text { - A passion to work for reasons that } \\
\text { go beyond money or status } \\
\text { - A propensity to pursue goals with } \\
\text { energy and persistence }\end{array}$ & $\begin{array}{l}\text { - Strong drive to achieve } \\
\text { - Optimism in the face of } \\
\text { failure } \\
\text { - Organisational } \\
\text { commitment }\end{array}$ \\
\hline Empathy & $\begin{array}{l}\text { - The ability to understand the } \\
\text { emotional make-up of other people } \\
\text {-Skill in treating people according to } \\
\text { their emotional reactions }\end{array}$ & $\begin{array}{l}\text { - Expertise in building } \\
\text { and retaining talent } \\
\text { - Cross-cultural } \\
\text { sensitivity } \\
\text { - Service to clients and } \\
\text { customers }\end{array}$ \\
\hline Social skill & $\begin{array}{l}\text {-Proficiency in managing } \\
\text { relationships and building networks } \\
\text {-An ability to find common ground } \\
\text { and build rapport }\end{array}$ & $\begin{array}{l}\text { - Effectiveness in leading } \\
\text { change } \\
\text { - Persuasiveness } \\
\text { - Expertise in building } \\
\text { and leading teams }\end{array}$ \\
\hline
\end{tabular}

Source: Goleman, 2004, p. 101 
Figure 4 below identifies the behavioural competencies that would significantly enhance leadership performance. These competencies bear resemblance to the five components of Goleman's emotional intelligence.

As could be gauged from Figure 4, working cohesively together would relate to Goleman's social skill while reliability, credibility, accountability, honesty and integrity. The willingness to accept change would relate to Goleman's self-regulation component of emotional intelligence. Good manners and respect for seniors would relate to empathy while willingness to go the extra mile and a culture of continuous learning would relate to Goleman's motivational aspect of emotional intelligence.

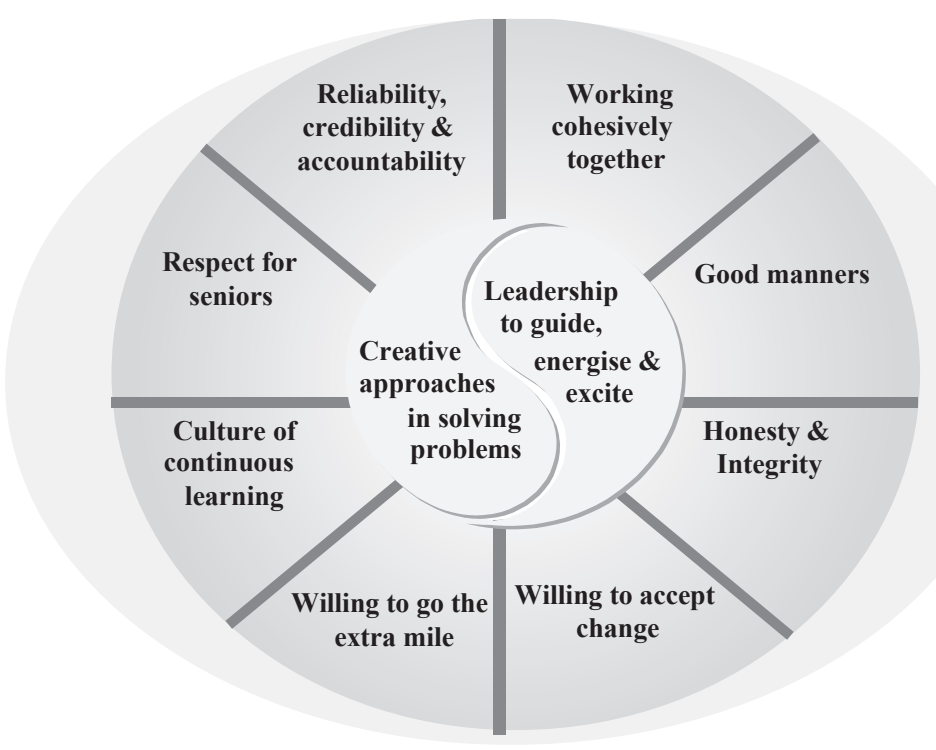

Figure 4: Behavioural Competencies of Leaders

Adapted from: Fulmer, 1997, p. 72

Recent research at the Centre for Creative Leadership (CCL) has uncovered links between specific elements of emotional intelligence and specific behaviours associated with leadership effectiveness (Velsor and McCaulay, 2004, p. 276). Feedback can positively impact an individual's effectiveness as a leader. Feedback deepens that leader's self-awareness about the impact of his/her behaviour on others. Much leadership development feedback naturally affects how people think about themselves, not just their interactions with others. Similarly, it can lead to re-evaluations of many aspects of one's life, not just one's role as a leader. It can affect the whole person. It follows then that in some ways leadership development itself involves the development of the whole person. 
Leaders are expected to be a role model, to inspire, coach and act as mentor. They are expected to be people of character - basically honest and fair and equitable in outlook. In the words of Emerson, the actions of leaders speak so loudly that you cannot but hear them. They should also be proactive, transparent, caring and goal-focused. Those in leadership roles must be high in self-motivation and discipline. They should give meaning to the future, catalyse the organisation, build staff commitment, enable others to make change happen and remain true to their goals (Powell, 1995, p. 76).

Braveheart Wallace offers insights into real leadership when he confronts the selfish and cowardly Scottish nobles: "You think the people of this country exist to provide you with position. I think your position exists to provide those people with freedom."

The quote above points us to the focus of a healthy leadership. Leaders should serve the people. We, as public service leaders, should ask reflect on the motive of our leadership. Real leadership is service not position.

In 1970 Robert Greenleaf published his essay on leadership - "The Servant Leader". The secular world heralded it as a seminal piece, although religious leaders in history had long advocated such leadership (see Greenleaf, 2012). For example, 150 years before Greenleaf got it, D.L. Moody had said: "The measure of a man is not how many servants he has, but how many men he serves."

Real leadership is also about influence and not position. To have immense influence over one's subordinates, a public service leader should care about his or her subordinates' needs. As the saying goes, employees don't care how much you know but care how much you care! A public service leader must be proactive in making sure his subordinates get promoted faster. If that is not the case, he should ensure that his officers are coached and mentored to become high performers so that they rise up the civil service fast.

Some of the greatest leaders in history lead without the trappings of position or title. Nelson Mandela freed South Africa from Apartheid without any title or position. During his incarceration for over a quarter of a century, his ideas were tearing away at an ostensibly unassailable government. Ghandi too had no title or authority. Yet, despite being imprisoned four times, he was able to bring down the British and free India. Similarly, Ninoy Aquino, with no position and title, imprisoned seven years and then exiled in the US ended Marcos' rule in the Philippines. Similarly, Jimmy Carter left the Oval Office in shame in 1980 after suffering one of the worst defeats in US presidential history. During the next twenty years, Carter won back his influence through service by building houses for the poor. Some consider 
Carter to be more respected than when he was in office.

People view leadership as authority over people. But leadership is more about guiding than demanding. Guides go first. They set an example for others to follow. They do not push, pull, or drag. They simply lead. ${ }^{2}$ Leadership is also about influence. William Wallace, with no title and position, led the Scots in their fight for freedom from the English. His admonishment of the Scottish nobles, "Your title gives you claim to the throne of the country, but men don't follow titles, they follow courage," says much about influence being the quintessential quality of a leader, which influence is predicated upon courage.

\section{Technical Skills VS People Skills}

We have heard this before - a leader surrounds himself with followers who are better than him. True, a leader needs to provide leadership and set the direction. The troops will help accomplish it. A study by the Stanford Research Institute and Carnegie Mellon Foundation involving Fortune 500 chief executive officers confirms that $75 \%$ of long-term job success depended on people skills, and only $25 \%$ on technical knowledge. However, in providing leadership, the leader will have to have a handle of things. And this is where the $25 \%$ technical knowledge comes into play. A leader needs to be technically adept so that he can speak the language of his subordinates and be on the ball. A leader must know as much as anybody, if not more, about the technical and financial aspects of the job (Giuliani, 2002, p. 242). For example, in the Ministry of Health, the director-general can leave it to the surgeon to implement his policies on surgery. But to devise a policy, say, on post-surgical care, he must know something about surgery.

\section{Developing Leaders}

The ultimate leader is one who is willing to develop people to the point that they eventually surpass him or her in knowledge and ability. Fred A. Manske Jr.

Organisations today are faced with the challenge of ensuring the continued availability of capable leaders through succession planning. The public service is no exception. It is faced with the necessity of grooming potential leaders. Identifying and developing people with potential for higher

\footnotetext{
${ }^{2}$ Every Nation, Position or Power? http://www.everynation.org/en/top/features/random-thoughts/Position-or -Power.html
} 
leadership positions are a hallmark of a leader. As Jack Welch says, a potential leader develops himself before he becomes a leader. Once he becomes a leader his business becomes growing other leaders.

This statement that leaders grow leaders has become a deep universal belief. The leadership development programmes of many major corporations such as General Electric, Johnson \& Johnson, Levi Strauss, PepsiCo, Australia Post and Hewlett-Packard attest to the significance of developing leaders. Furthermore, best practice organisations recognise leadership as a key component in jobs at all levels and are committed to creating leaders throughout their organisations (Goleman et. al, 2002, p. 143).

Often the question comes up, "So where do you begin in growing new leaders?" Often, the answers go firstly, "Who?", then, "What?" and lastly, "How?" The basic "what" is about what we want our future leaders to be like, to behave like, to be able to do and how their priorities should change as they move from individual contributor, to team leader or first level supervisor and eventually a senior leader or top manager. This is why we start with some of our best leaders - the Who - because they are the ones who determine where the organisation should head in the future. We want leaders to develop the leadership brand. Such a leadership brand ensures that employee behaviour is aligned to the needs of the citizens (Ulrich and Smallwood, 2007, p.132).

\section{The question how?}

When we look at history, we see that many great leaders were great teachers. Leaders like Gandhi and Martin Luther King Jr. were able to revolutionize the way people saw the world, teach a new vision and establish new behaviours. They were strong leaders and were able to transform some of their disciples into leaders. If they were unable to do this, their vision might have been short-lived. The more leaders reproduce themselves, the more likely it is that they do emerge, paradoxically, with heroic accomplishments. For example, Mandela considers himself as just an ordinary man who had to rise up to extraordinary circumstances His speeches are filled with praise for others. He even forgave his former prison guards. Yet he achieved true greatness and international acclaim for his leadership (Mandela, 2004, p. 149). Ivan Seidenberg could share the $\mathrm{CEO}$ role twice in the mergers that produced Verizon because he put the needs of the institution first over his own. The reward for sharing was an even bigger winning company

Jack Welch, Sam Walton (of Wal-Mart) and Matsushita believed in developing people. As curious leaders they were life-long learners. They 
paid attention to people knowing that the success of any enterprise hinged on giving subordinates the maximum opportunity to succeed. General Gordon R. Sullivan once said, "Great leaders produce great subordinates who, in turn, become great leaders in their own time." Leaders are considered a success when they are able to identify, sustain and inspire other talented people. In nurturing budding leaders, the leader must institute a regular feedback mechanism to monitor progress and effectiveness in moulding his followers into leaders (Velsor and McCauley, 2004 p. 231).

The approach to leadership development in many organisations is eventsbased rather than systemic. One method of making leadership development more systemic is to make sure it involves more than training. An array of developmental experiences must be designed and implemented that are meaningfully integrated with one another.

These leadership development initiatives would include performance support and development of skills through such methods as training programmes, coaching and mentoring, action learning and developmental assignments. Combining instruction with a real business setting helps people gain crucial skills while allowing organisations to attack relevant, crucial and real-time issues. The goal of leadership development, ultimately, involves action not merely knowledge. Therefore, leadership development would mean providing people opportunities to learn from their work rather than taking them away from their work to learn.

Increasingly, organisations have CEOs who promote leadership development through teaching leaders internally (Spenser, 2006, p. 76). For example, Carly Fiorina, formerly at Hewlett Packard, was annually teaching at 12 leading business results classes. The participants of leadership development programmes are no longer relatively isolated individuals who are picked by senior management. Rather, individuals picked for such training programmes are likely to include those with leadership potential from all levels of the organisation (Fulmer, 1997, p. 70).

Development programmes can improve the capacity of public service leaders and help groom potential leaders. But taught courses are not the best way for adults to learn. Neither is it the most effective approach to mould leaders. $90 \%$ of the learning is through informal learning (Ulrich and Smallwood, 2007, p. 221). Bennis' study (Best Practices in Leadership Development, 1999) reported that informal learning was effective due to active learning from and exposure to senior leaders' experiences (as opposed to traditional classroom learning). Leadership development has to include crucible experience, that is, learning from experience. Bennis wrote that the crucible experience is "both an opportunity and a test. It is a defining moment that unleashes abilities, forces crucial choices and 
sharpens focus. It teaches a person who he or she is."

Crucible experience can be complemented with mentoring and coaching by senior leaders. Coaching and mentoring are one of the tools employed by the Canadian, British, Swedish, Australian and Singapore public services to nurture potential leaders. There, new recruits who show leadership potential are put under the tutelage of senior officers and are mentored till they reach the senior position for which they were mentored for.

The dual challenges of understanding the nature of leadership development and implementing effective leadership development practices will likely be greater than ever before. Leadership development practices will need to become better integrated into the broader context of organisational business challenges. Thus, not only will organisations need to hire and develop leaders, they will also need to be the kind of organisations that nurture and reinforce the kinds of behaviours desired in those leaders. Meeting such challenges will be one important thrust of public service leaders in the years to come.

\section{Conclusion}

Although the environment in the public and private sectors are different, leadership skills are essentially the same. It is only a matter of degree which skills are the more important in either of the two sectors. Leadership in the public service requires analytical and technical skills as well as the soft skills of empathy, caring, motivation and self-regulation. While analytical and technical skills are threshold capabilities, what are more important are the soft skills. Influence is particularly important in a public service leader given the bureaucratic environment in which he leads. Being able to influence his followers in the way they should go and in accomplishing the goals is a mark of true leadership.

To be a great leader in the public service one would also need to invest in developing people, especially, leaders. This would require coaching and mentoring potential leaders so that the latter can assume senior positions in the future. Leaders should spend time developing those behind them, even if it is at the cost of not advancing their career. Succession planning should be high on their management agenda. A good leader is one who can ensure that there is continued excellence long after he or she has left the organisation. The sacrifice of time and effort at mentoring and coaching

\footnotetext{
i This picture won an Oscar in 1995 for the Best Motion Picture.

ii We can do so by constantly innovating in service delivery.

${ }^{\text {iii }}$ As they say, God is in the details. Trifles make for perfection and perfection is no trifle.
} 
potential leaders will make a public service leader leave behind a lasting legacy of his leadership.

\section{REFERENCES}

Batta, G. (2001). A Cross-Jurisdictional Scan of Practices in Senior Public Services: Implications for New Zealand. Working Paper No. 13. Wellington: State Services Commission.

Batley, R. (2006). The Changing Role of the State. In Munawar Alam and Andrew Nickson (Ed.), Managing Change in Local Governance. London: Commonwealth Secretariat.

Bennis, W. (1999). Best Practices in Leadership Development Handbook: Case Studies, Instruments, Training. In David Giber, Louis Carter, Marshall Goldsmith (Ed.), Asia: John Wiley \& Sons.

Canton, J. (2006). The Top Trends that will Shape the World in the Next 20 Years. New York: Institute for Global Futures.

Collins, J. (2001). Good to great. New York: HarperCollins.

Friedman, T (2006). The World is Flat. London: Penguin Books.

Fulmer. R.M. (1997).The Evolving Paradigm of Leadership Development. Organisational Dynamics.

25(4), 59-73.

Gladwell, M (2000). Tipping Point Leadership. London: Abacus.

Goleman, D (2004). What makes a leader? In The Mind of the Leader. Harvard Business Review. Boston: Harvard Business Review Press. pp. 97-122.

Goleman, D., Boyatzis, R., \& McKee, A. (2002). Primal leadership. Boston: Harvard Business School Press.

Giuliani, R (2002). Leadership. New York: Brown Little.

Government of Sri Lanka (2010). Mahinda Chintana: Vision for the Future. http:// www.preventionweb.net/files/28587_mahindachintanavisionforthefutureen.pdf (accessed on 7 th November 2013).

Greenleaf, R.K (2012). The Servant as Leader. New York: The Greenleaf Centre for Servant Leadership. 60 pages

Harari, O (1996). The Leadership Secrets of Colin Powell. New York: McGrow-Hill. Heller, R (2001). Jack Welch. London: Dorling Kindersley.

Ismail Adam (Tan Sri) (2006). Enhancing Workforce Excellence in the Public Sector. Public Management Journal. Public Service Department Malaysia. Putrajaya: Public Service Department. pp. 1-17

Ismail Adam (Tan Sri) (2005). Leadership in the Malaysian Public Sector: An Update. Public Management Journal. Public Service Department Malaysia. Putrajaya: Public Service Department. pp. 1-22.

Kim W.C and R. Mauborgne (2005). Blue Ocean Strategy: How To Create Uncontested Market Space and Make The Competition Irrelevant. Boston: Harvard Business School Press.

Kotter, J. and H.Rathgerber (2006). Our Iceberg is Melting: Changing and Succeeding 
Under Any Circumstances. New York: St. Martin's Press.

Liff, S. (2007). Managing Government Employees. New York: American Management Association.

Maira, A. (2002). Shaping the Future: Aspirational Leadership in India and Beyond. Singapore: John Wiley \& Sons.

Powell, C. (1995). My American Journey: An Autobiography. New York: Random House.

Mandela, N. (2004). Long Walk to Freedom. Volume 2: 1962-1994. London: Abacus.

McKinsey \& Co. (2001). Effective Capacity Building in Nonprofit Organisations. Report prepared for Venture Philanthropy Patners. Available from http://vppartners. org/learning/reports/capacity/capacity.html (accessed on 7th November 2013)

Roselena Lazemi and Siti Norlailasari (2007). Public Sector Leadership Study. Putrajaya: Public Service Department.

Spencer, S.M. et. al (2007). The Indian CEO: A Portrait of Excellence. New Delhi: Response Books

Ulrich, D. and N.Smallwood (2007). Leadership Brand. Boston: Harvard Business School Press. Van Velsor, E. \& McCauley. C.D. (2004). Our View of Leadership Development. In C.D McCauley and E. Van Velsor (eds.), The Center for Creative Leadership Handbook of Leadership Development (2nd ed.). San Francisco: Jossey-Bass. 